\title{
Complexation-Distribution Separated Solvent Extraction Process Designed for Rapid and Efficient Recovery of Inert Platinum Group Metals
}

\author{
Zhiwei Zheng, ${ }^{1}$ Tsuyoshi Arai, ${ }^{2}$ Koichiro Takao ${ }^{1 *}$ \\ ${ }^{1}$ Laboratory for Zero-Carbon Energy, Institute of Innovative Research, Tokyo Institute of \\ Technology, 2-12-1 N1-32, 0-okayama, Meguro-ku, 152-8550 Tokyo, Japan. \\ ${ }^{2}$ Graduate School of Engineering, Shibaura Institute of Technology, 3-7-5, Toyosu, Koto-ku, 135-8548 Tokyo, \\ Japan.
}

*To whom correspondence should be addressed. E-mail: takao.k.ac@m.titech.ac.jp.

\section{List of Contents}

Figure. S1. Schematic structure and ${ }^{1} \mathrm{H}$ and ${ }^{13} \mathrm{C}$ assignments of TMPDA.

Figure. S2. ${ }^{1} \mathrm{H}$ NMR spectrum of TMPDA in $\mathrm{CDCl}_{3}$. (a): upper field. (b): lower field. $\quad$ S3

Figure. S3. ${ }^{13} \mathrm{C}\left\{{ }^{1} \mathrm{H}\right\}$ NMR spectrum of TMPDA in $\mathrm{CDCl}_{3}$ S3

$\begin{array}{lr}\text { Figure. S4. ATR-FTIR spectrum of TMPDA. } & \text { S4 }\end{array}$

Figure. S5. Schematic structure and ${ }^{1} \mathrm{H}$ and ${ }^{13} \mathrm{C}$ assignments of DEDMPDA. S4

Figure. S6. ${ }^{1} \mathrm{H}$ NMR spectrum of DEDMPDA in $\mathrm{CDCl}_{3}$. (a): upper field. (b): lower field. $\quad \mathrm{S} 4$

Figure. S7. ${ }^{13} \mathrm{C}\left\{{ }^{1} \mathrm{H}\right\}$ NMR spectrum of DEDMPDA in $\mathrm{CDCl}_{3}$. S5

$\begin{array}{ll}\text { Figure. S8. ATR-FTIR spectrum of DEDMPDA. } & \text { S5 }\end{array}$

Figure. S9. Schematic structure and ${ }^{1} \mathrm{H}$ and ${ }^{13} \mathrm{C}$ assignments of TEPDA. S5

Figure. S10. ${ }^{1} \mathrm{H}$ NMR spectrum of TEPDA in $\mathrm{CDCl}_{3}$. (a): upper field. (b): lower field. $\quad$ S6

Figure. S11. ${ }^{13} \mathrm{C}\left\{{ }^{1} \mathrm{H}\right\}$ NMR spectrum of TEPDA in $\mathrm{CDCl}_{3}$. S6

$\begin{array}{lr}\text { Figure. S12. ATR-FTIR spectrum of TEPDA. } & \text { S6 }\end{array}$

Figure. S13. Schematic structure and ${ }^{1} \mathrm{H}$ and ${ }^{13} \mathrm{C}$ assignments of DMDPPDA. S7

Figure. S14. ${ }^{1} \mathrm{H}$ NMR spectrum of DMDPPDA in $\mathrm{CDCl}_{3}$. (a): upper field. (b): lower $\quad \mathrm{S} 7$ field.

Figure. S15. ${ }^{13} \mathrm{C}\left\{{ }^{1} \mathrm{H}\right\}$ NMR spectrum of DMDPPDA in $\mathrm{CDCl}_{3}$.

$\begin{array}{lr}\text { Figure. S16. ATR-FTIR spectrum of DMDPPDA. } & \text { S8 }\end{array}$ 
Figure. S17. Schematic structure and ${ }^{1} \mathrm{H}$ and ${ }^{13} \mathrm{C}$ assignments of DEDPPDA.

Figure. S18. ${ }^{1} \mathrm{H}$ NMR spectrum of DEDPPDA in $\mathrm{CDCl}_{3}$. (a): upper field. (b): lower field.

Figure. S19. ${ }^{13} \mathrm{C}\left\{{ }^{1} \mathrm{H}\right\}$ NMR spectrum of DEDPPDA in $\mathrm{CDCl}_{3}$. (a): upper field. (b): lower field.

Figure. S20. ATR-FTIR spectrum of DEDPPDA.

Figure. S21. Progress of absorbance at $450 \mathrm{~nm}(\mathrm{Ru}(\mathrm{III}))$ and $370 \mathrm{~nm}(\mathrm{Rh}(\mathrm{III}))$ at $356 \mathrm{~K}$ as functions of elapsed time.

Figure. S22. UV-visible absorption spectra of $0.5 \mathrm{M} \mathrm{HNO}_{3}(\mathrm{aq})$ containing $5 \mathrm{mM} \mathrm{Ru}(\mathrm{III})$ (a) or $1.5 \mathrm{mM} \mathrm{Rh}$ (III) (b) with $30 \mathrm{mM}$ TMPDA at $298 \mathrm{~K}$.

Figure. S23. Effect of concentration of TEPDA to $\mathrm{Ru}(\mathrm{NO})^{3+}$ and $\mathrm{Rh}^{3+}$ extraction from $0.5 \mathrm{M} \mathrm{HNO}_{3}(\mathrm{aq})$ to 1-octanol in terms of $D$. The experimental procedure: $\mathrm{HNO}_{3}$ (aq) solution containing $5 \mathrm{mM} \mathrm{Ru}(\mathrm{NO})^{3+}$ or $\mathrm{Rh}^{3+}$ with $2-120 \mathrm{mM}$ TEPDA was heated at $356 \mathrm{~K}$ for $5 \mathrm{~h}$, and then was mixed with 1-octanol with $500 \mathrm{mM} \mathrm{LiTf}_{2} \mathrm{~N}$ for $5 \mathrm{~min}$ at room temperature.

Figure. S24. Effect of total concentration of $\mathrm{Tf}_{2} \mathrm{~N}^{-}$to $\mathrm{Ru}(\mathrm{NO})^{3+}$ and $\mathrm{Rh}^{3+}$ extraction from $0.5 \mathrm{M} \mathrm{HNO}_{3}(\mathrm{aq})$ to 1 -octanol in terms of $D$. Experiment processes and conditions: The $\mathrm{HNO}_{3}$ (aq) containing $5 \mathrm{mM} \mathrm{Ru}(\mathrm{NO})^{3+}$ or $\mathrm{Rh}^{3+}$ with $30 \mathrm{mM}$ TEPDA was heated at $356 \mathrm{~K}$ for $5 \mathrm{~h}$ as complexation process in Figureure 2. After cooling down to RT, the aqueous solution was stirred for 5 min with 1octanol containing 0.15-1 M LiTf $2 \mathrm{~N}$ as distribution process in Figureure 2.

Figure. S25. ${ }^{1} \mathrm{H}$ NMR spectra of $0.5 \mathrm{M} \mathrm{HNO}_{3}(\mathrm{aq})\left(10 \% \mathrm{D}_{2} \mathrm{O}\right)$ containing TEPDA after heating at $356 \mathrm{~K}$ for $0,2,5,23$ and $46 \mathrm{~h}((\mathrm{a}): 7.2-8.4 \mathrm{ppm}$. (b): 0.7-3.4 ppm) and ${ }^{1} \mathrm{H}$ NMR spectra of $0.5 \mathrm{M} \mathrm{HNO}_{3}(\mathrm{aq})\left(10 \% \mathrm{D}_{2} \mathrm{O}\right)$ containing 2, 6pyridinedicarboxylic acid (c) or diethylamine (d).

Figure. S26. ${ }^{1} \mathrm{H}$ NMR spectra of $0.5 \mathrm{M} \mathrm{HNO}_{3}(\mathrm{aq})\left(10 \% \mathrm{D}_{2} \mathrm{O}\right)$ containing $30 \mathrm{mM}$ TEPDA and $5 \mathrm{mM} \mathrm{Ru}(\mathrm{NO})^{3+}$ at $356 \mathrm{~K}$. (a): 7.2-8.4 ppm. (b): 0.7-3.4 ppm.

Figure. S27 ${ }^{1} \mathrm{H}$ NMR spectra of $0.5 \mathrm{M} \mathrm{HNO}_{3}(\mathrm{aq})\left(10 \% \mathrm{D}_{2} \mathrm{O}\right)$ containing $30 \mathrm{mM}$ TEPDA and $5 \mathrm{mM}$ Rh at $356 \mathrm{~K}$. (a): 7.2-8.4 ppm. (b): 0.7-3.4 ppm.

Figure. S28. ORTEP drawing of $\mathrm{Ru}(\mathrm{NO})^{3+}$ complex with 2,6-pyridinedicarboxylate and 6 -(diethylcarbamoyl)picolinate at the $50 \%$ probability level. Hydrogen atoms were omitted for clarity.

Table S1. Calculated Logarithmic Gross Stability Constant $\left(\log \beta_{n}\right)$ of $\left[\mathrm{Ru}(\mathrm{NO})(\mathrm{TEPDA})_{n}\right]^{3+}$ and $\left[\operatorname{Rh}(\mathrm{TEPDA})_{n}\right]^{3+}(n=1,2)$ in Aqueous Phase under Different Concentration of PDA 


\section{Characterization of PDA Ligands.}

The water-soluble PDA ligands were prepared as follows and characterized by ${ }^{1} \mathrm{H}$ and ${ }^{13} \mathrm{C} N M R$ (JEOL JNM ECX-400) and IR spectroscopy (JASCO FT/IR-4700 with diamond prism ATR apparatus).<smiles>CCN(CC)C(=O)c1cccc(C(=O)N(C)C2CCCCC2)n1</smiles>

Figure. S1. Schematic structure and ${ }^{1} \mathrm{H}$ and ${ }^{13} \mathrm{C}$ assignments of TMPDA.

(a)

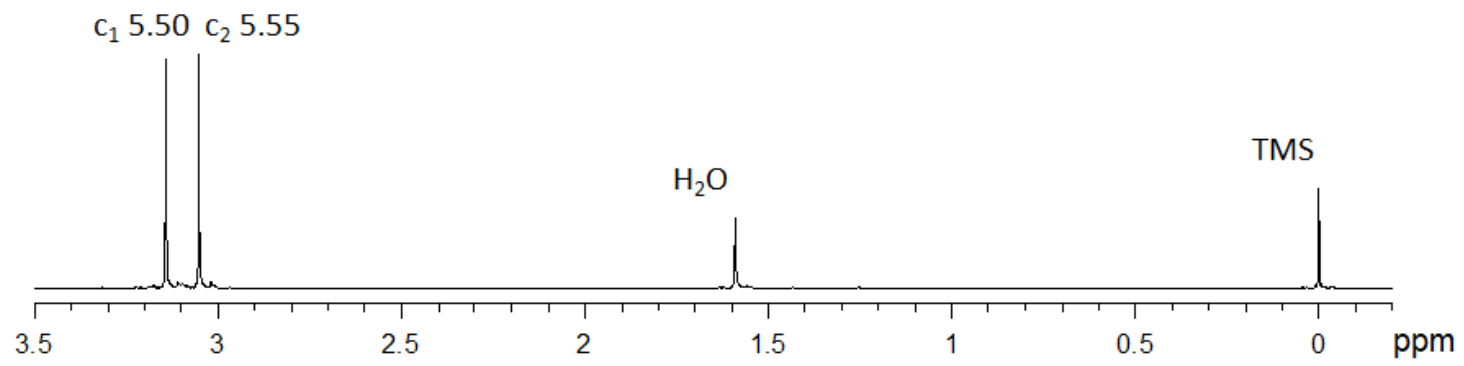

(b)

$\mathrm{CDCl}_{3}$

b 1.92

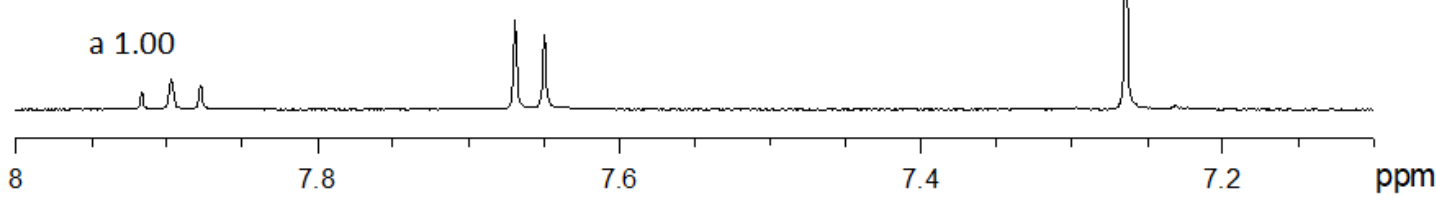

Figure. S2. ${ }^{1} \mathrm{H}$ NMR spectrum of TMPDA in $\mathrm{CDCl}_{3}$. (a): upper field. (b): lower field.

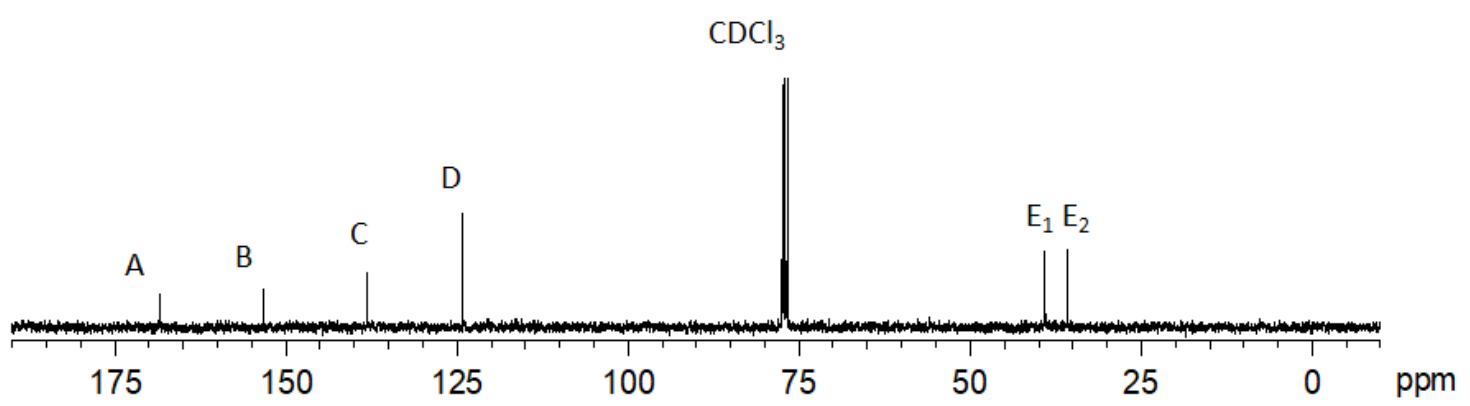

Figure. S3. ${ }^{13} \mathrm{C}\left\{{ }^{1} \mathrm{H}\right\}$ NMR spectrum of TMPDA in $\mathrm{CDCl}_{3}$. 


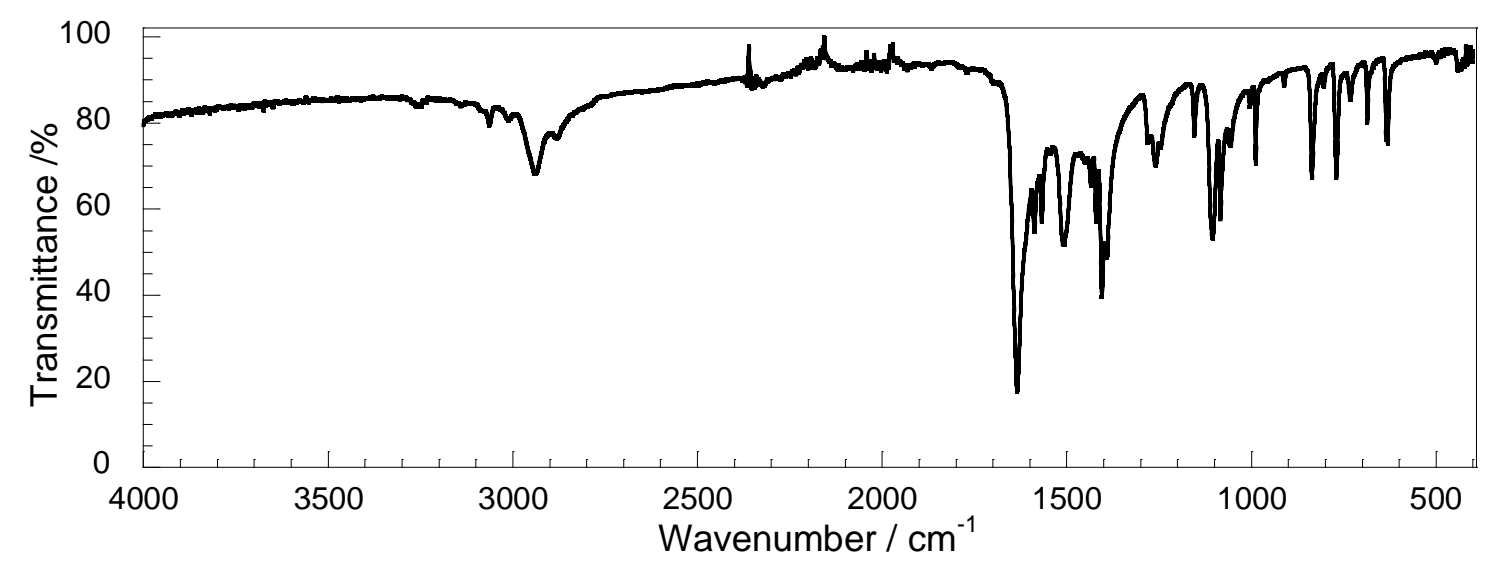

Figure. S4. ATR-FTIR spectrum of TMPDA.

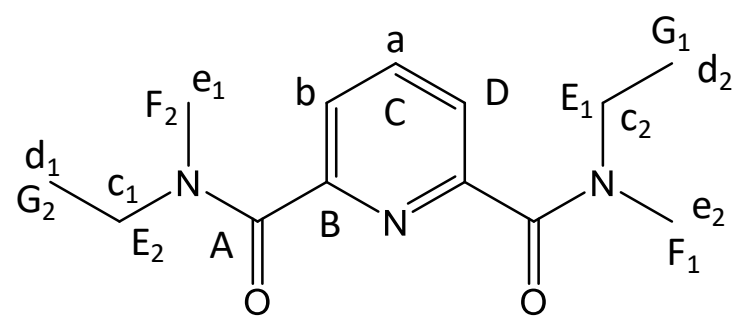

Figure. S5. Schematic structure and ${ }^{1} \mathrm{H}$ and ${ }^{13} \mathrm{C}$ assignments of DEDMPDA.

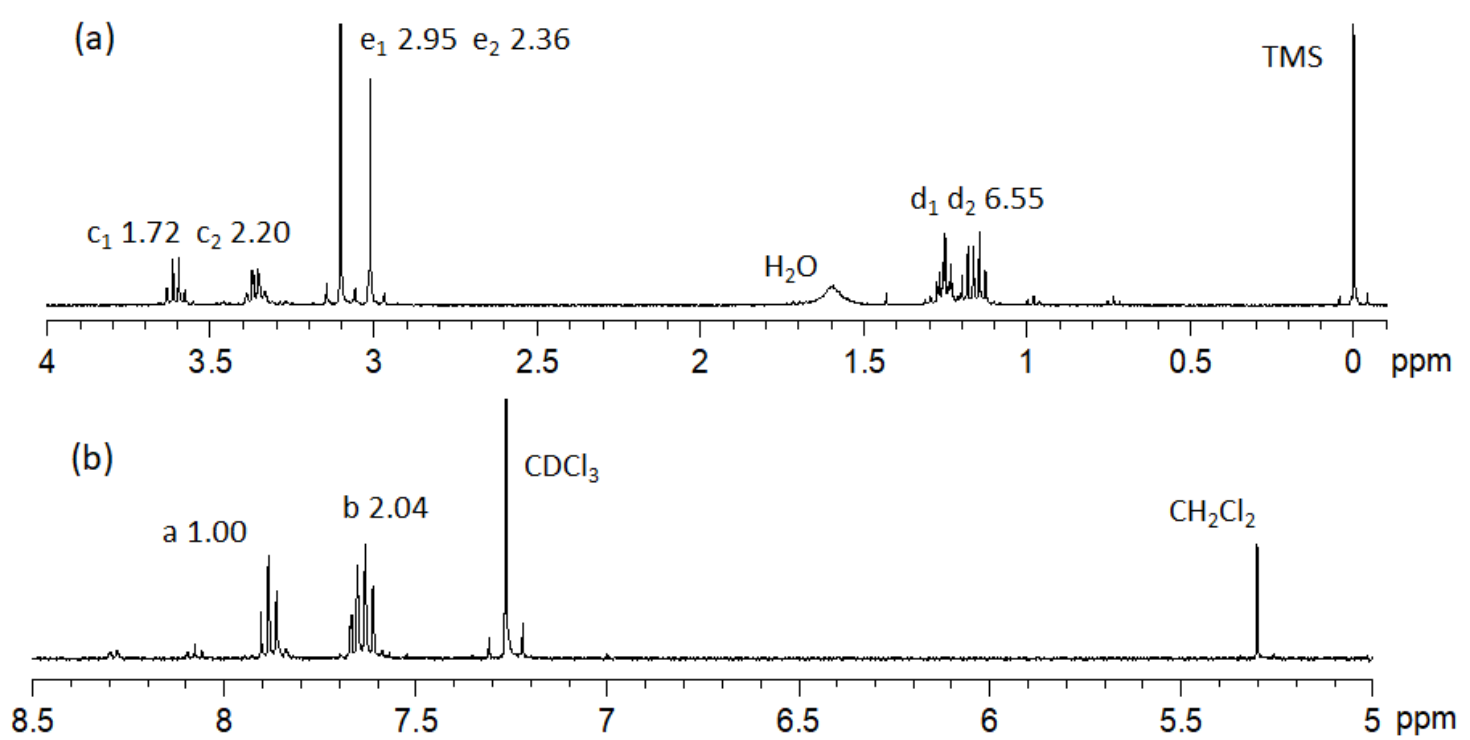

Figure. S6. ${ }^{1} \mathrm{H}$ NMR spectrum of DEDMPDA in $\mathrm{CDCl}_{3}$. (a): upper field. (b): lower field. 


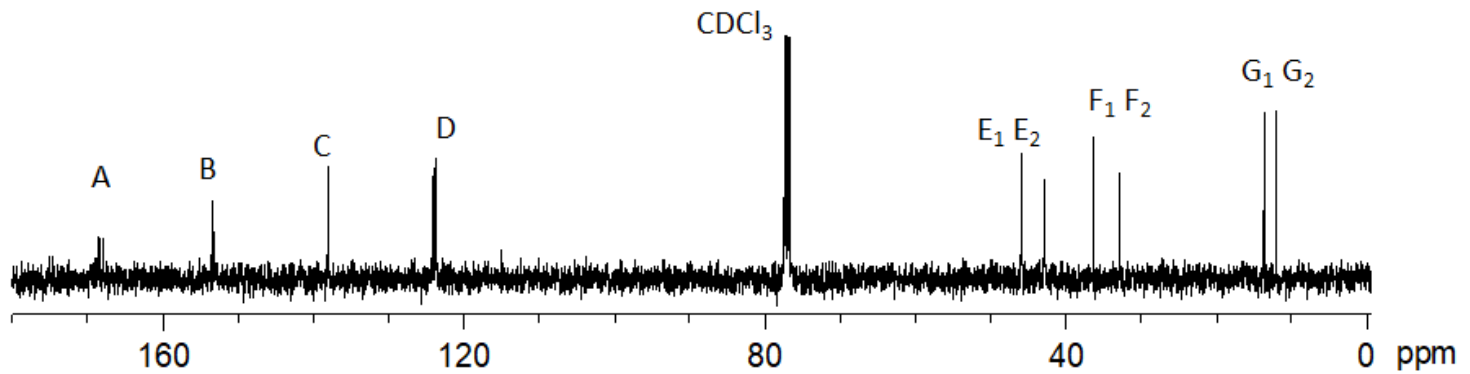

Figure. S7. ${ }^{13} \mathrm{C}\left\{{ }^{1} \mathrm{H}\right\}$ NMR spectrum of DEDMPDA in $\mathrm{CDCl}_{3}$.

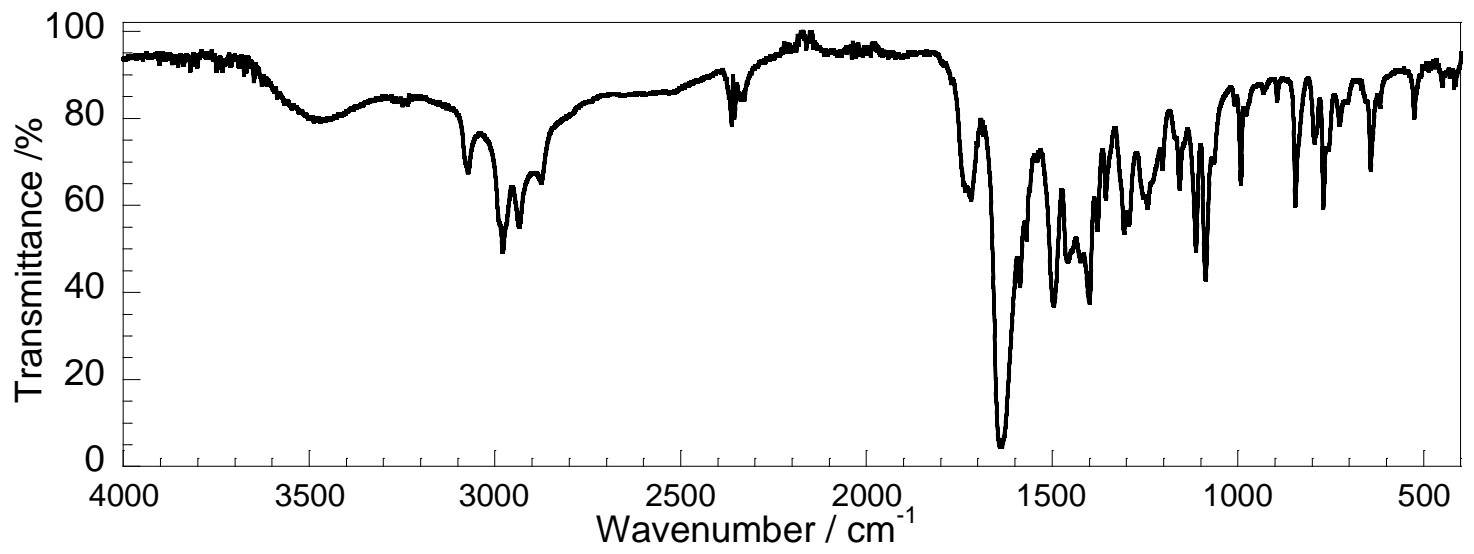

Figure. S8. ATR-FTIR spectrum of DEDMPDA.<smiles>[CH]CN(CC)C(=O)c1cccc(C(=O)N(CC)CF)n1</smiles>

Figure. S9. Schematic structure and ${ }^{1} \mathrm{H}$ and ${ }^{13} \mathrm{C}$ assignments of TEPDA. 


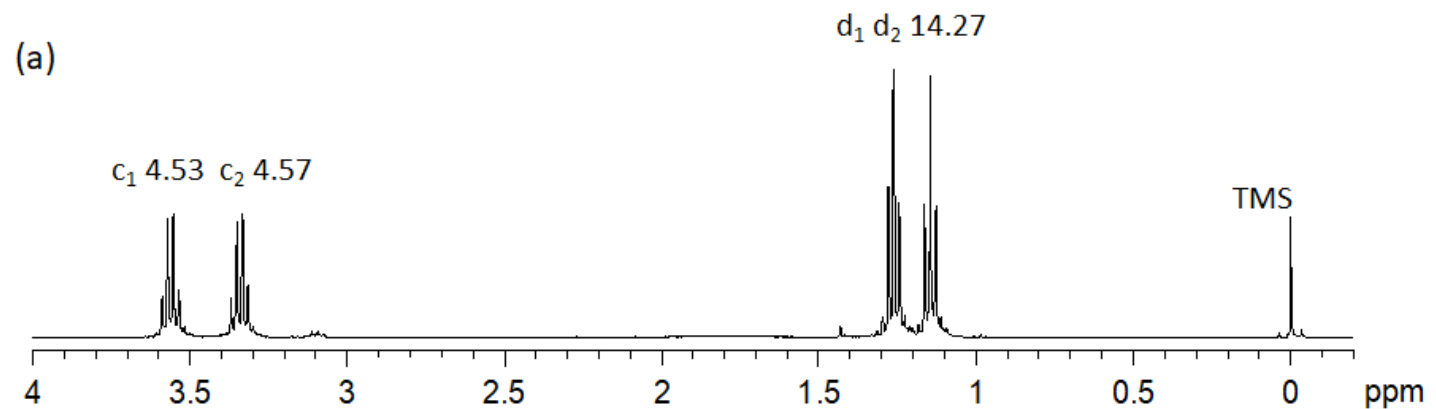

(b)

$$
\text { b } 2.06
$$

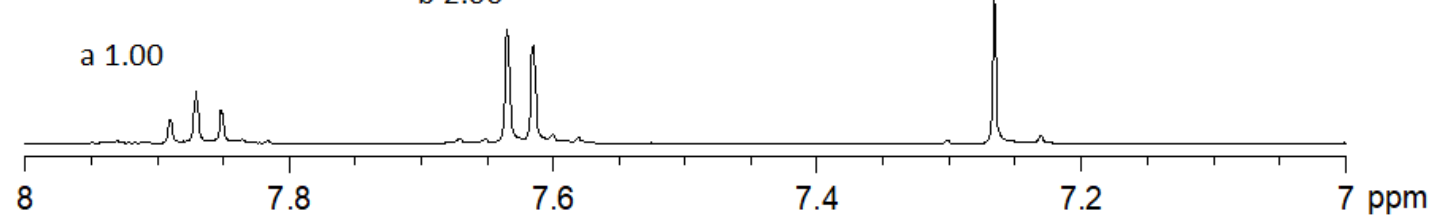

Figure. S10. ${ }^{1} \mathrm{H}$ NMR spectrum of TEPDA in $\mathrm{CDCl}_{3}$. (a): upper field. (b): lower field.

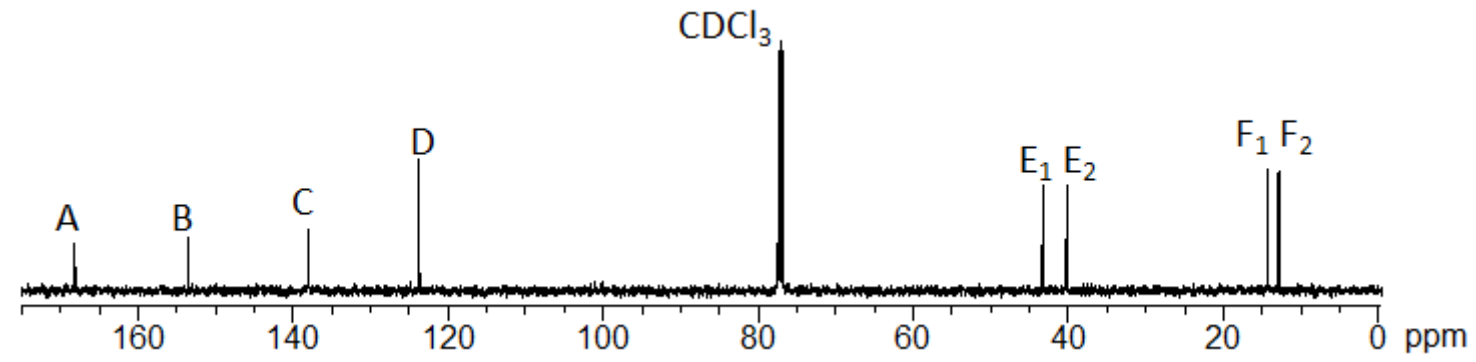

Figure. S11. ${ }^{13} \mathrm{C}\left\{{ }^{1} \mathrm{H}\right\}$ NMR spectrum of TEPDA in $\mathrm{CDCl}_{3}$.

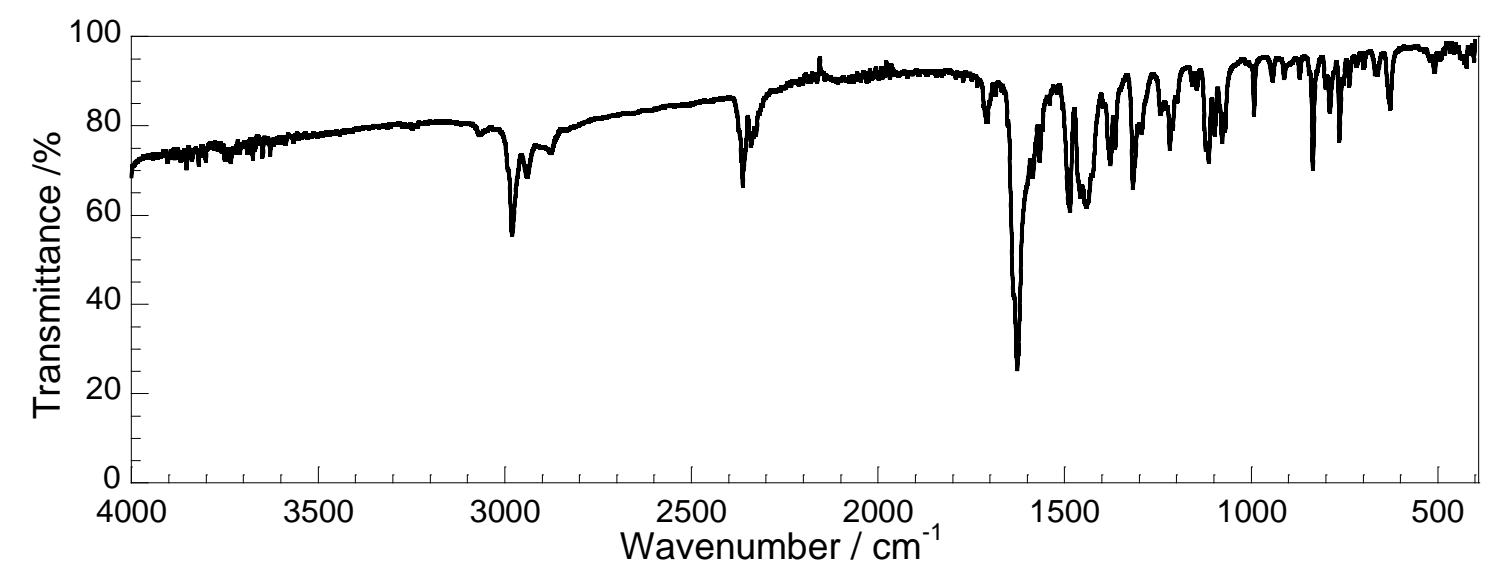

Figure. S12. ATR-FTIR spectrum of TEPDA. 


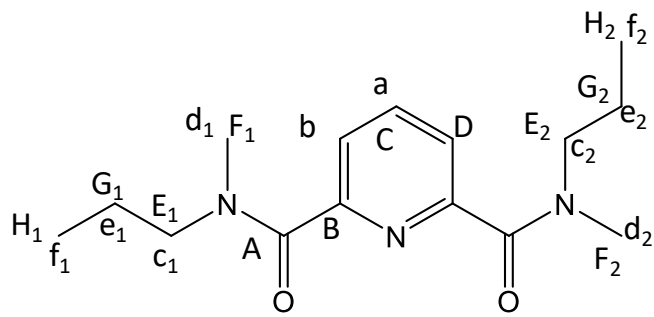

Figure. S13. Schematic structure and ${ }^{1} \mathrm{H}$ and ${ }^{13} \mathrm{C}$ assignments of DMDPPDA.

(a) $\quad d_{1} 3.75 d_{2} 2.86$

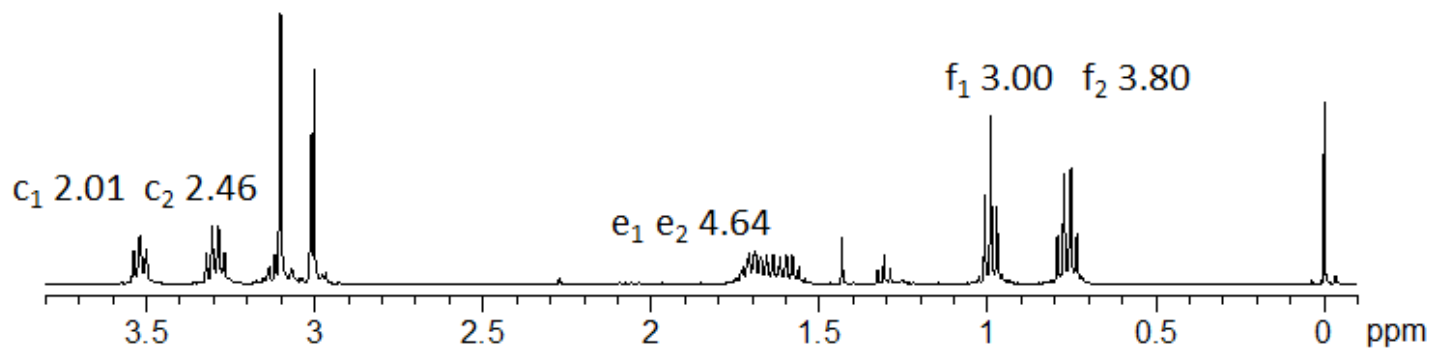

(b)

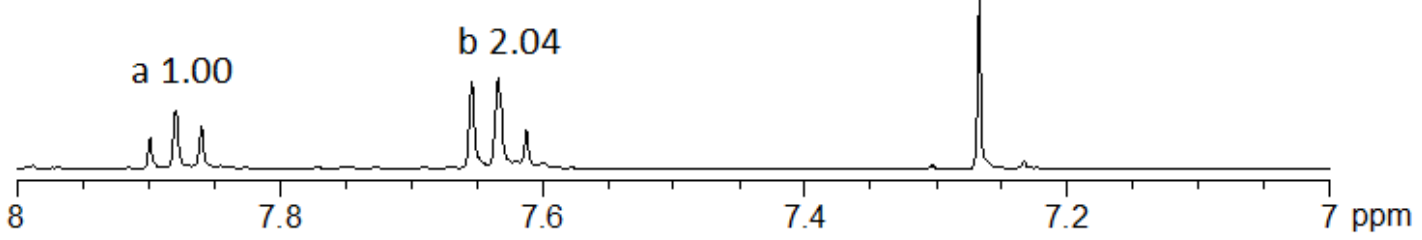

Figure. S14. ${ }^{1} \mathrm{H}$ NMR spectrum of DMDPPDA in $\mathrm{CDCl}_{3}$. (a): upper field. (b): lower field.

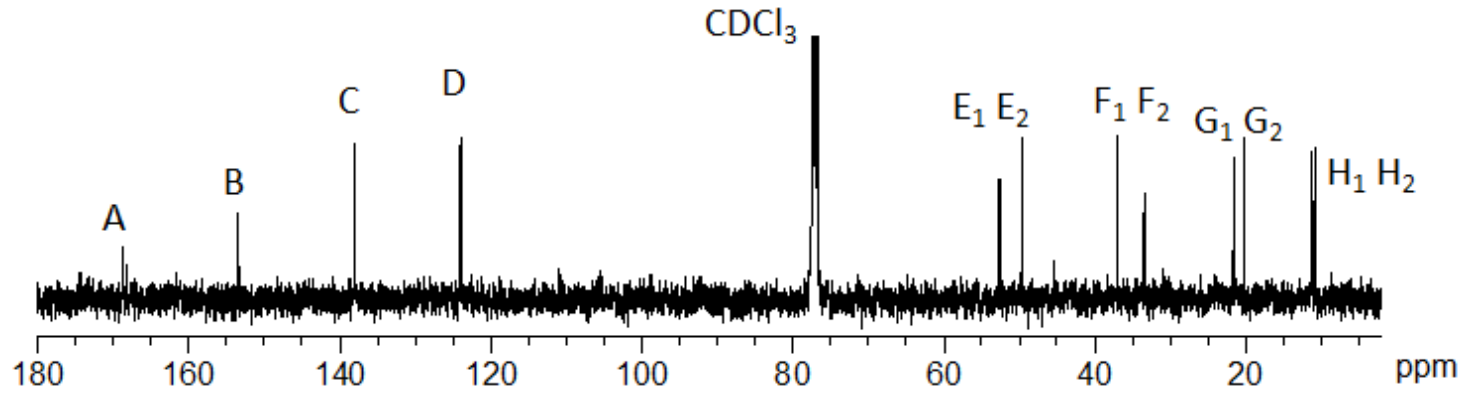

Figure. S15. ${ }^{13} \mathrm{C}\left\{{ }^{1} \mathrm{H}\right\}$ NMR spectrum of DMDPPDA in $\mathrm{CDCl}_{3}$. 


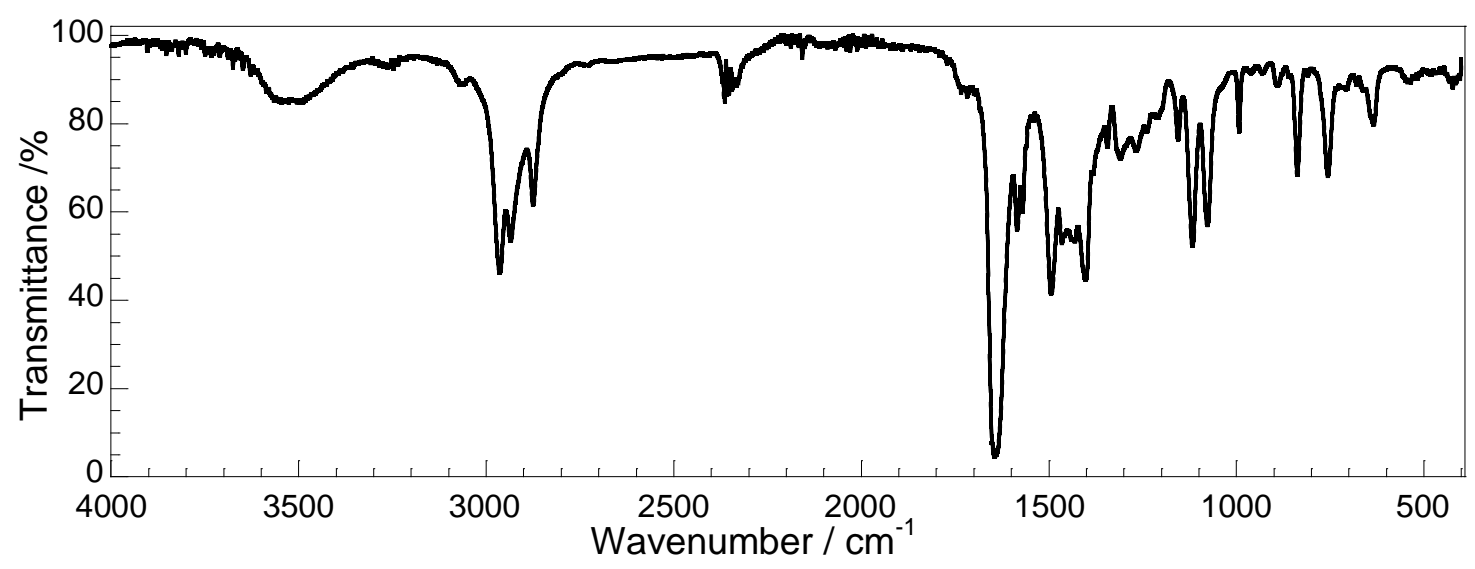

Figure. S16. ATR-FTIR spectrum of DMDPPDA.

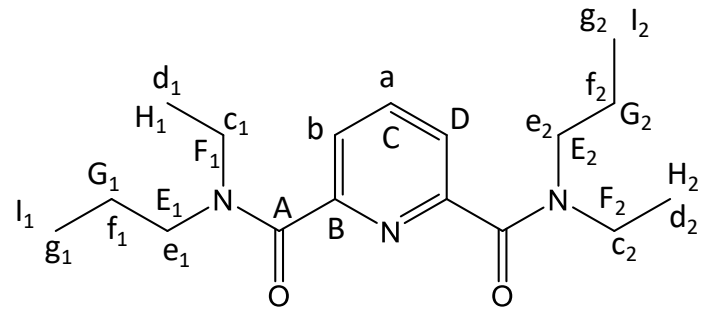

Figure. S17. Schematic structure and ${ }^{1} \mathrm{H}$ and ${ }^{13} \mathrm{C}$ assignments of DEDPPDA.

(a)

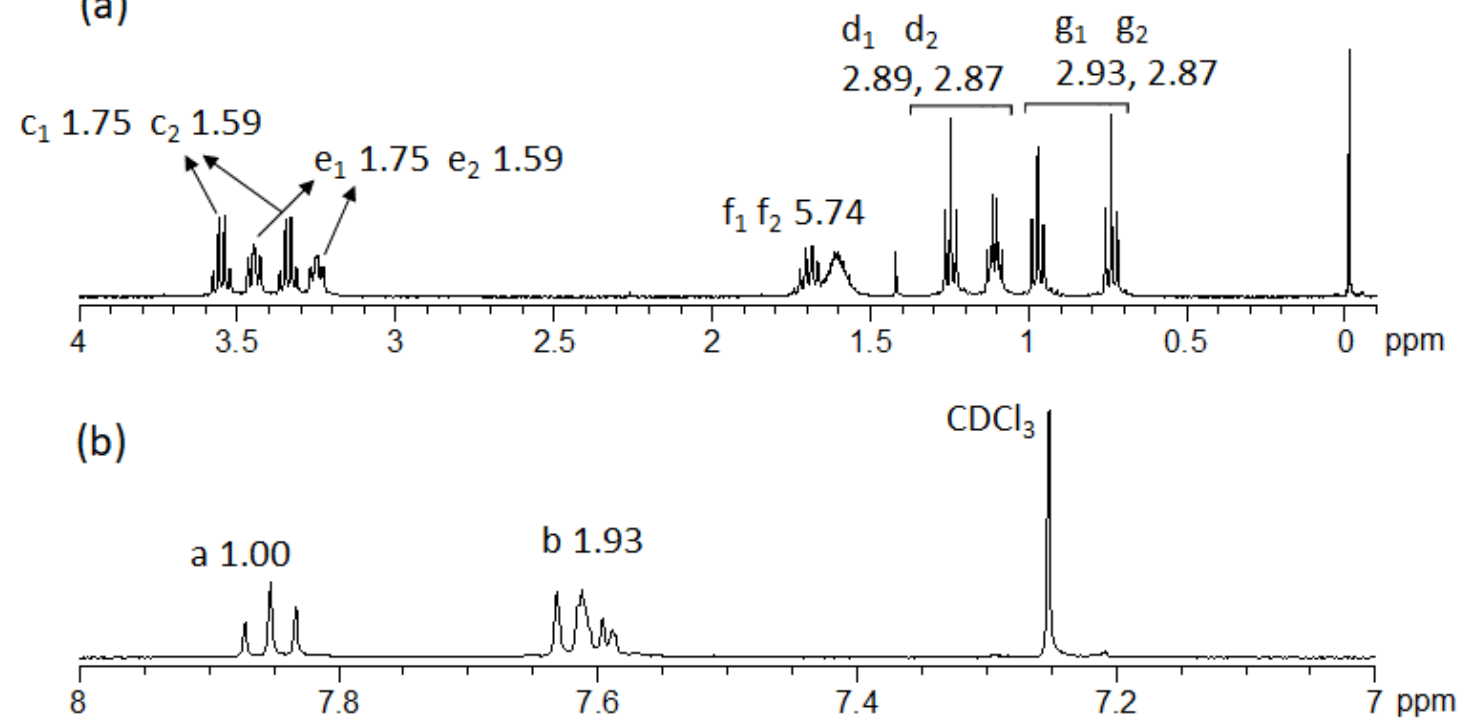

Figure. S18. ${ }^{1} \mathrm{H}$ NMR spectrum of DEDPPDA in $\mathrm{CDCl}_{3}$. (a): upper field. (b): lower field. 
(a)

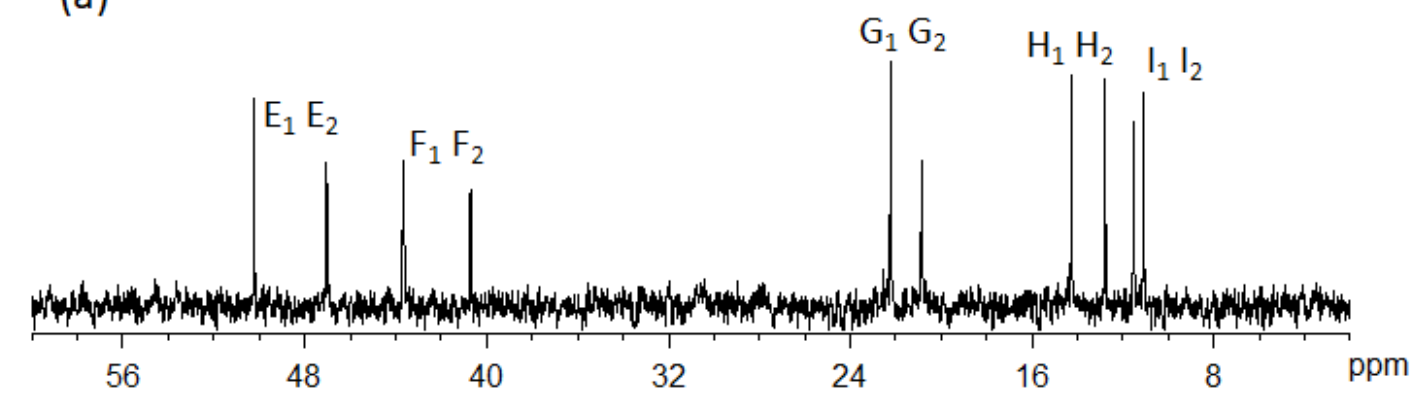

(b)

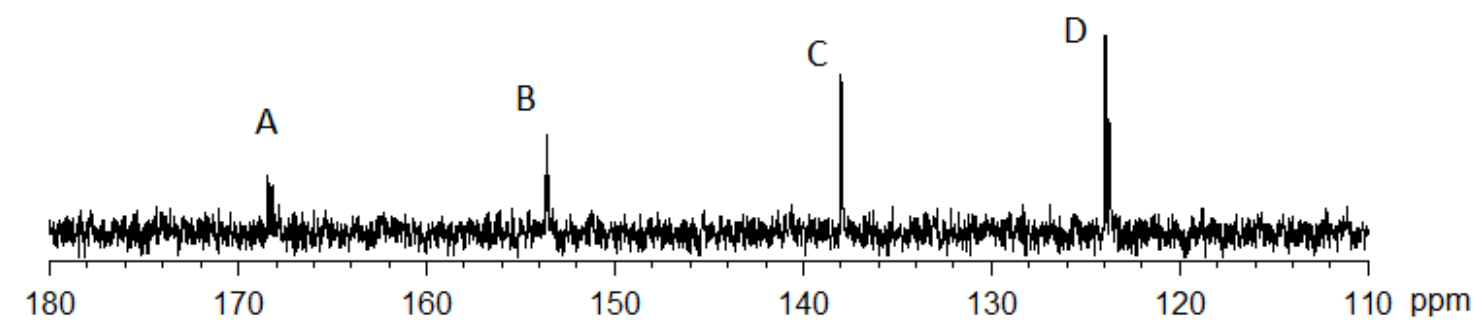

Figure. S19. ${ }^{13} \mathrm{C}\left\{{ }^{1} \mathrm{H}\right\}$ NMR spectrum of DEDPPDA in $\mathrm{CDCl}_{3}$. (a): upper field. (b): lower field.

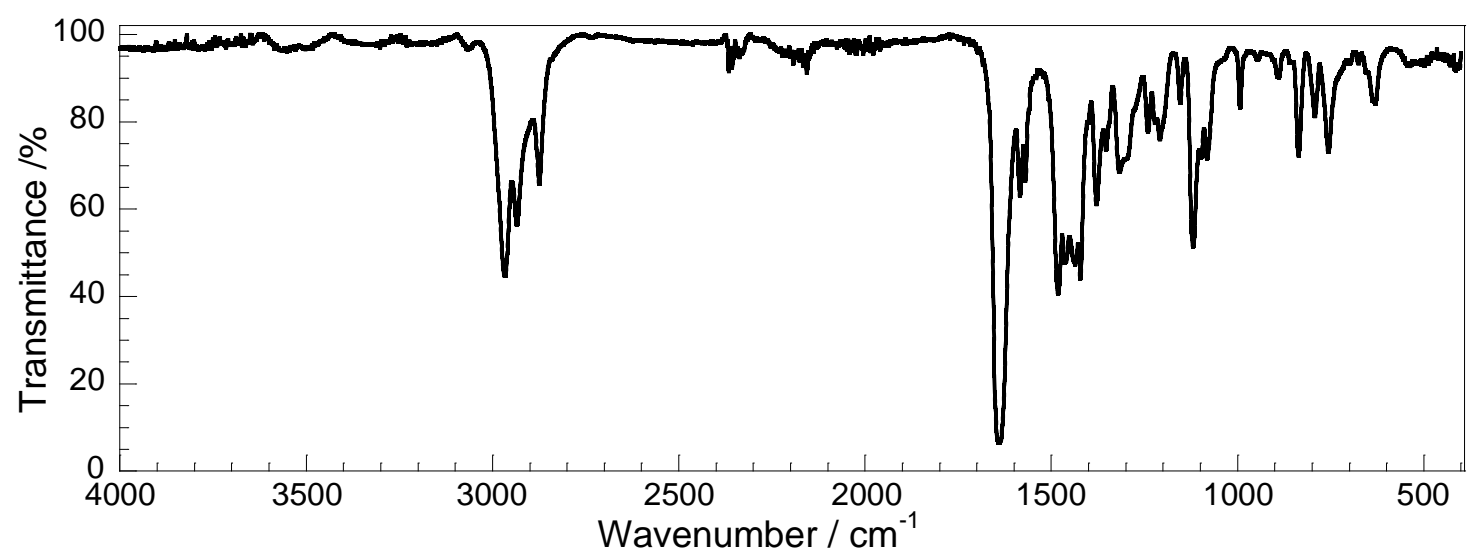

Figure. S20. ATR-FTIR spectrum of DEDPPDA. 

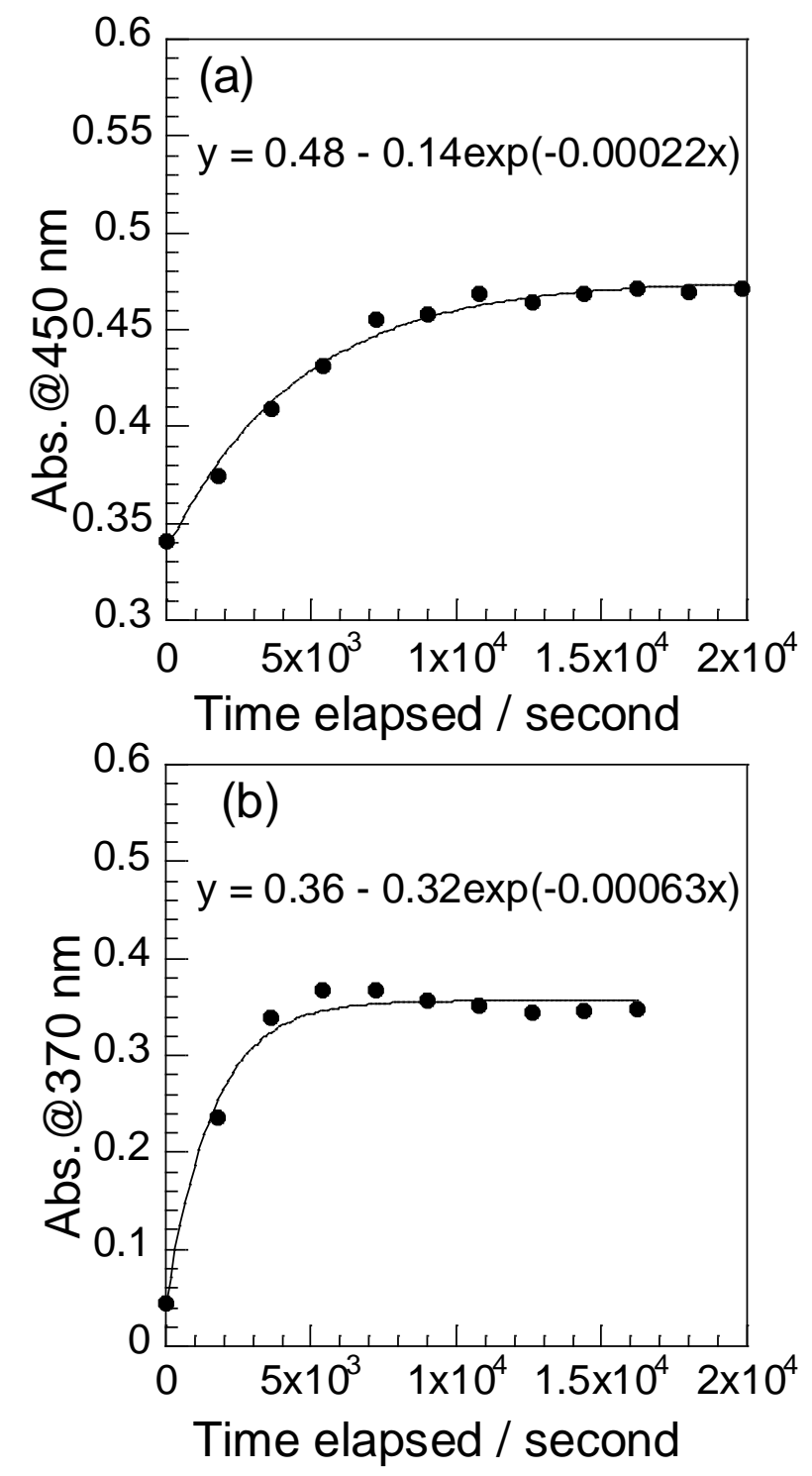

Figure. S21. Progress of absorbance at $450 \mathrm{~nm}(\mathrm{Ru}(\mathrm{III}))$ (a) and $370 \mathrm{~nm}(\mathrm{Rh}(\mathrm{III}))$ (b) at $356 \mathrm{~K}$ as functions of elapsed time. 

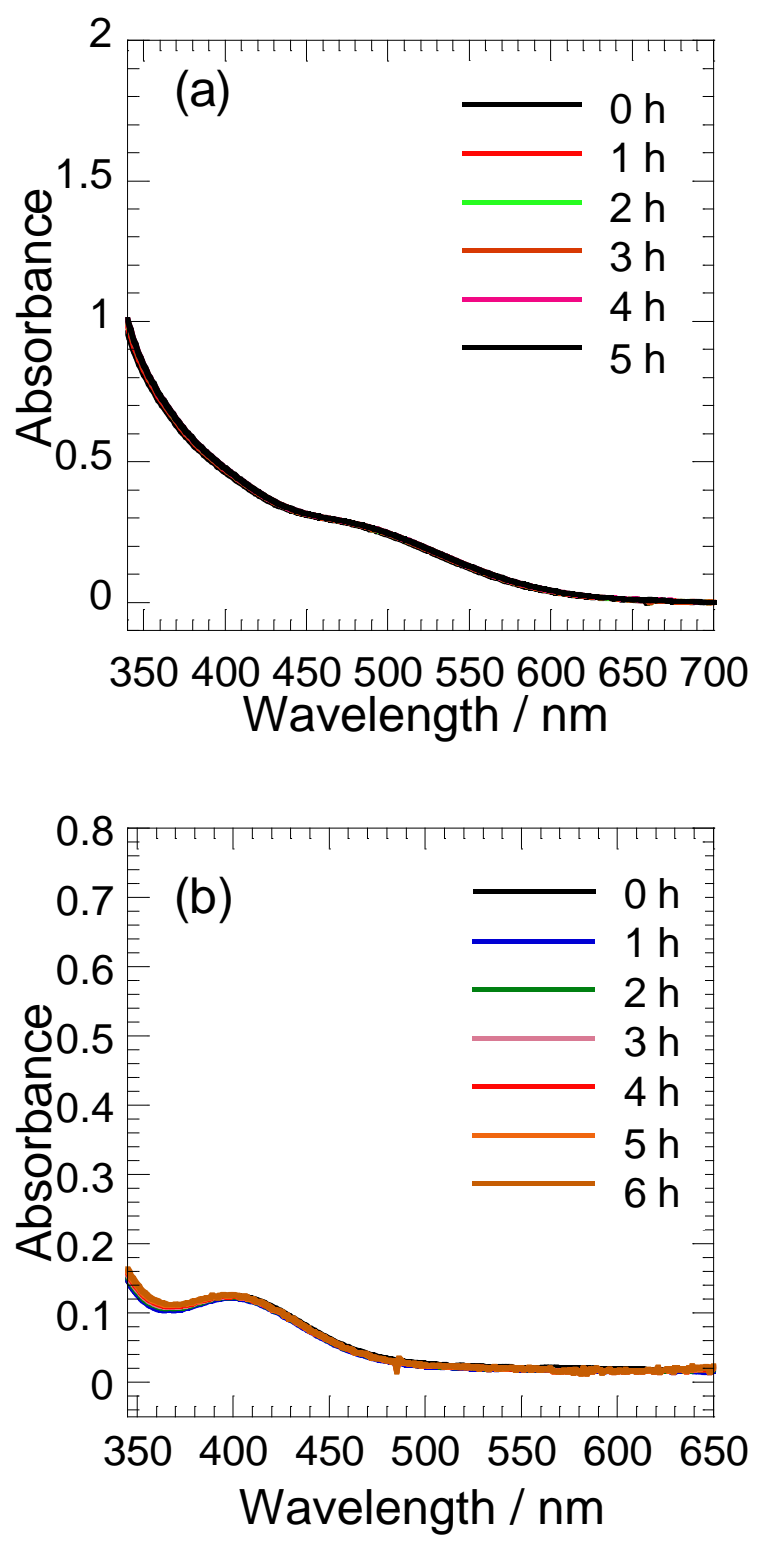

Figure. S22. UV-visible absorption spectra of $0.5 \mathrm{M} \mathrm{HNO}_{3}$ (aq) containing $5 \mathrm{mM} \mathrm{Ru}$ (III) (a) or $1.5 \mathrm{mM} \mathrm{Rh}(\mathrm{III})$ (b) with $30 \mathrm{mM}$ TMPDA at $298 \mathrm{~K}$. 


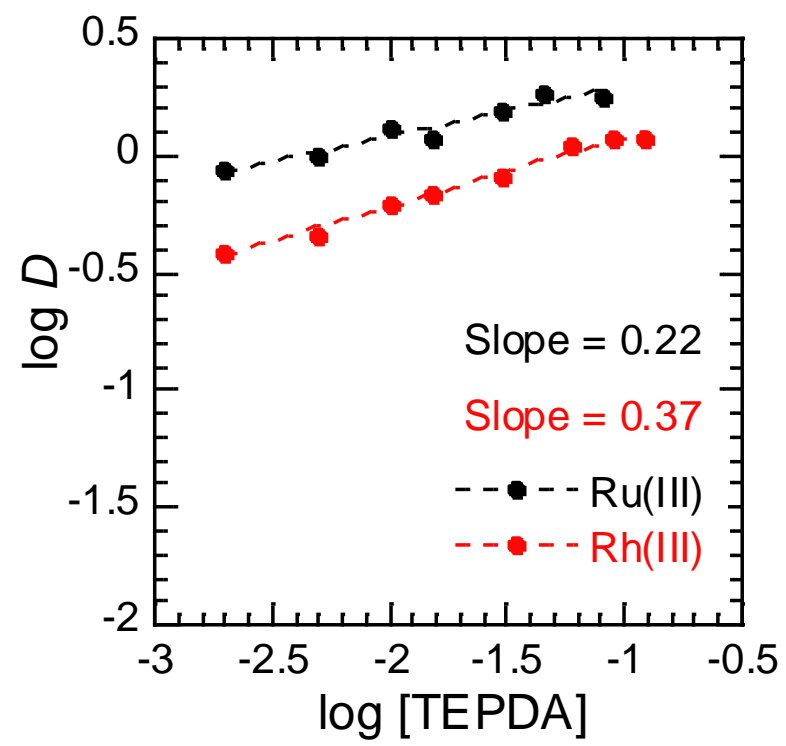

Figure. S23. Effect of concentration of TEPDA on $\mathrm{Ru}(\mathrm{NO})^{3+}$ and $\mathrm{Rh}^{3+}$ extraction from $0.5 \mathrm{M}$ $\mathrm{HNO}_{3}$ (aq) to 1-octanol in terms of $D$. The experimental procedure: $\mathrm{HNO}_{3}$ (aq) solution containing $5 \mathrm{mM} \mathrm{Ru}(\mathrm{NO})^{3+}$ or $\mathrm{Rh}^{3+}$ with 2-120 mM TEPDA was heated at $356 \mathrm{~K}$ for $5 \mathrm{~h}$, and then was mixed with 1-octanol with $500 \mathrm{mM} \mathrm{LiTf}{ }_{2} \mathrm{~N}$ for $5 \mathrm{~min}$ at room temperature.

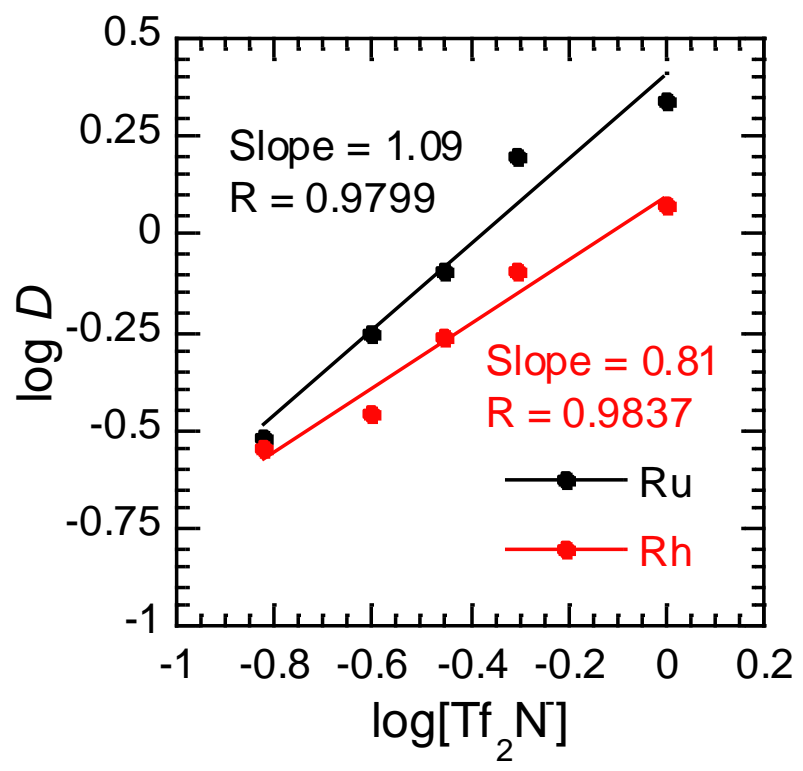

Figure. S24. Effect of total concentration of $\mathrm{Tf}_{2} \mathrm{~N}^{-}$to $\mathrm{Ru}(\mathrm{NO})^{3+}$ and $\mathrm{Rh}^{3+}$ extraction from $0.5 \mathrm{M}$ $\mathrm{HNO}_{3}$ (aq) to 1-octanol in terms of $D$. Experiment processes and conditions: The $\mathrm{HNO}_{3}(\mathrm{aq})$ containing $5 \mathrm{mM} \mathrm{Ru}(\mathrm{NO})^{3+}$ or $\mathrm{Rh}^{3+}$ with $30 \mathrm{mM}$ TEPDA was heated at $356 \mathrm{~K}$ for $5 \mathrm{~h}$ as complexation process in Figureure 2. After cooling down to RT, the aqueous solution was stirred for 5 min with 1-octanol containing 0.15-1 $\mathrm{M} \mathrm{LiTf}_{2} \mathrm{~N}$ as distribution process in Figurer 2 


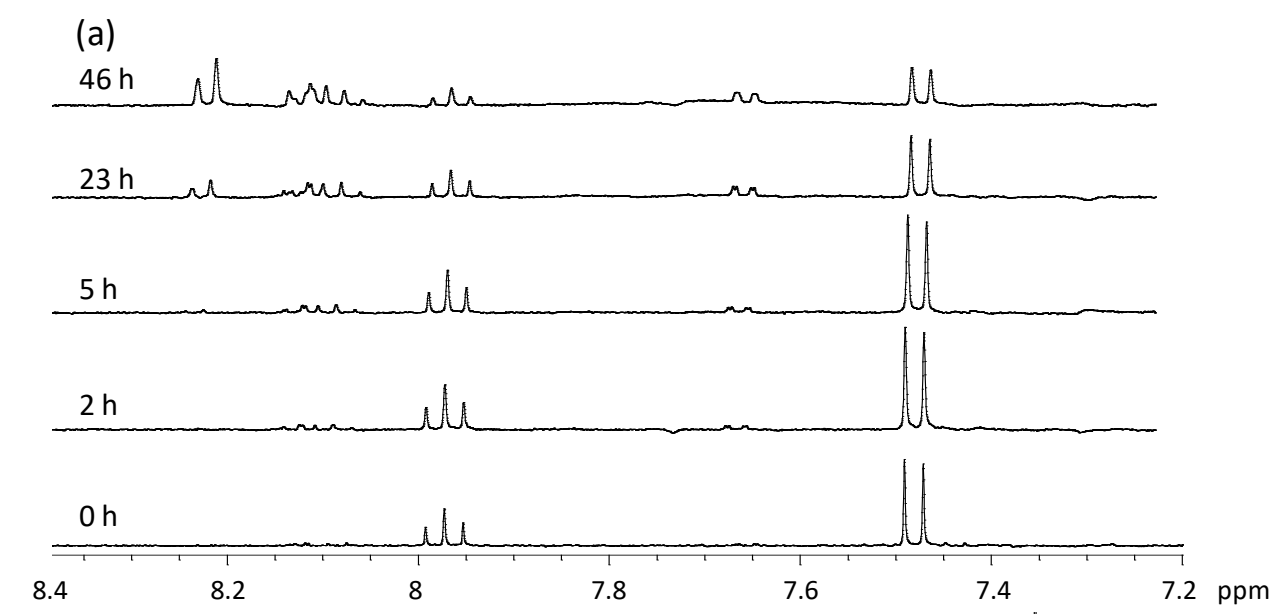

(b)

M M $46 \mathrm{~h}$

H.
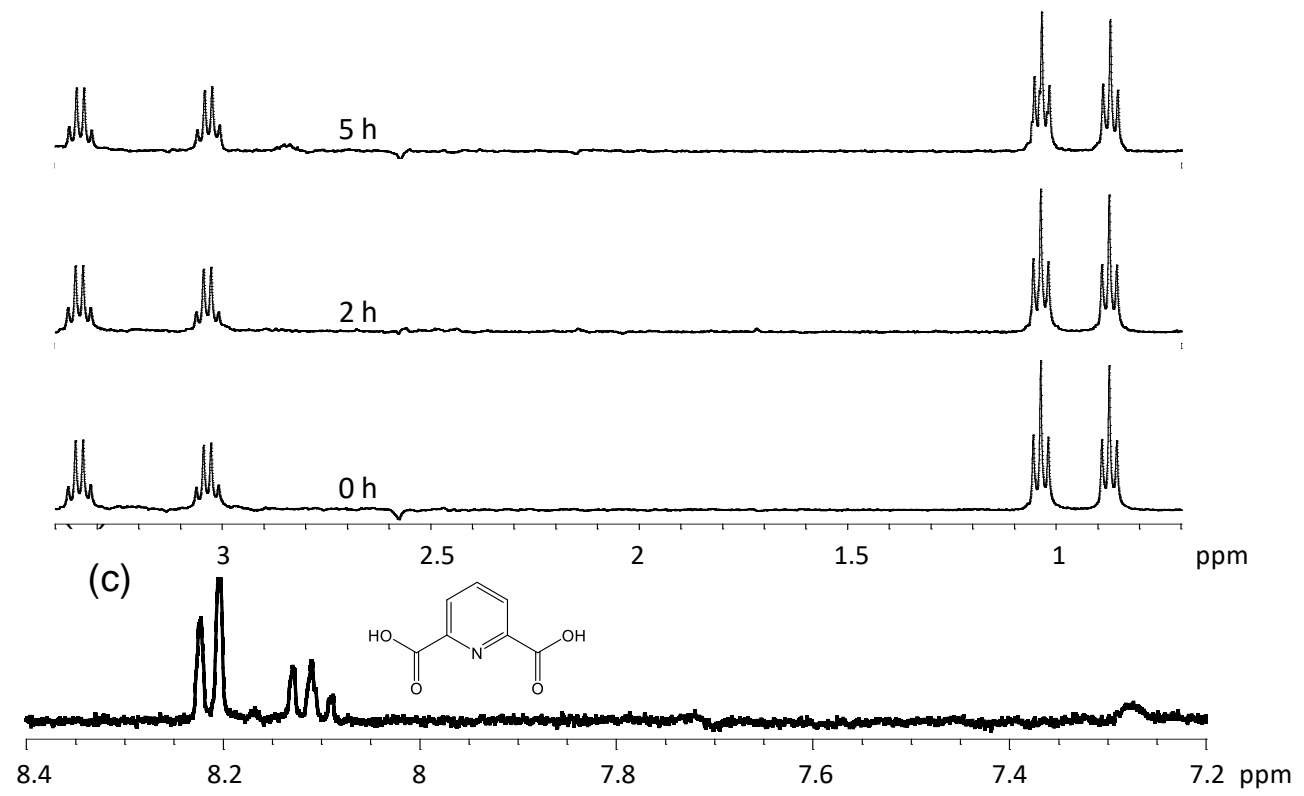

(d)

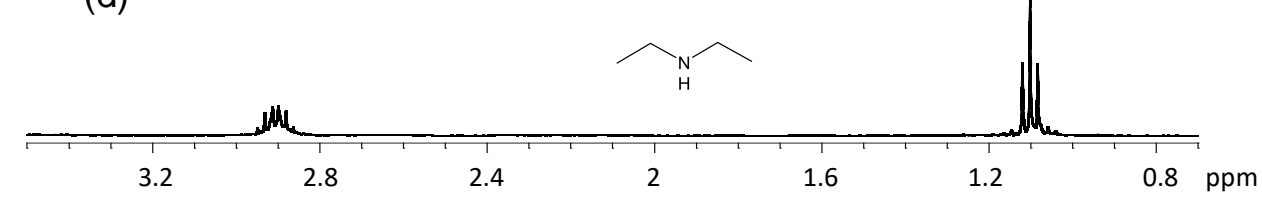

Figure. S25. ${ }^{1} \mathrm{H}$ NMR spectra of $0.5 \mathrm{M} \mathrm{HNO}_{3}(\mathrm{aq})\left(10 \% \mathrm{D}_{2} \mathrm{O}\right)$ containing TEPDA after heating at $356 \mathrm{~K}$ for 0, 2, 5, 23 and $46 \mathrm{~h}$ ((a): 7.2-8.4 ppm. (b): 0.7-3.4 ppm) and ${ }^{1} \mathrm{H}$ NMR spectra of $0.5 \mathrm{M}$ $\mathrm{HNO}_{3}(\mathrm{aq})\left(10 \% \mathrm{D}_{2} \mathrm{O}\right)$ containing, 2, 6-pyridinedicarboxylic acid(c) or diethylamine (d). 
(a)

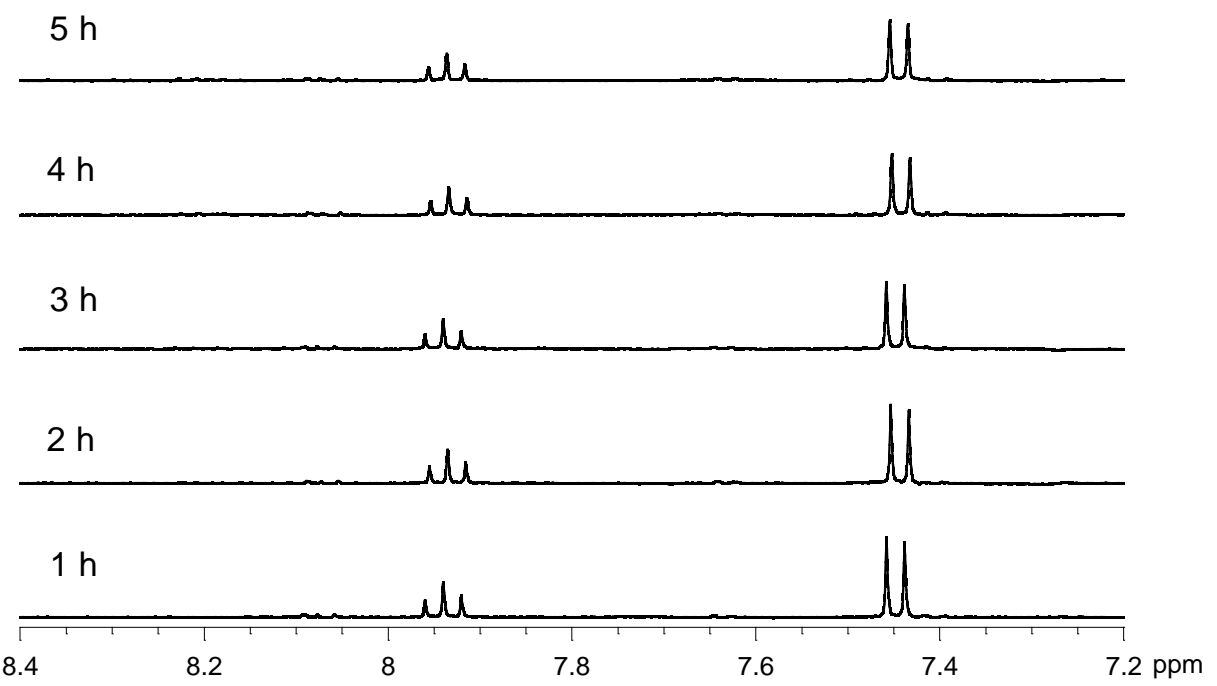

(b)

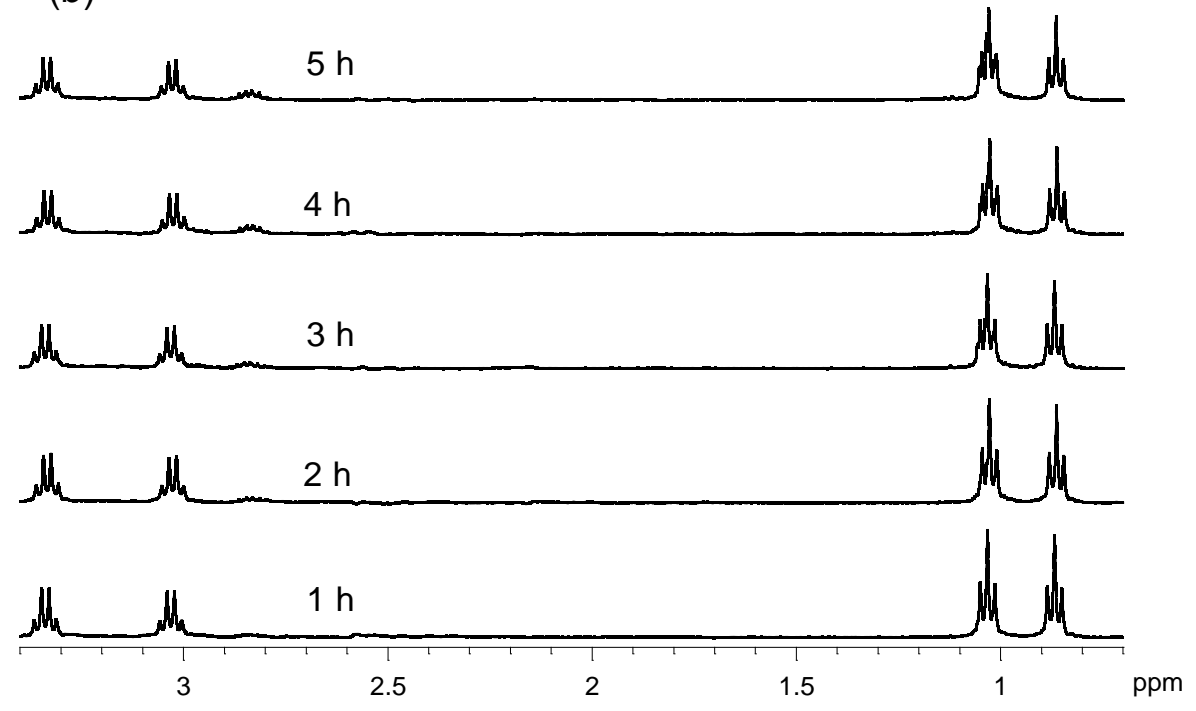

Figure. S26. ${ }^{1} \mathrm{H}$ NMR spectra of $0.5 \mathrm{M} \mathrm{HNO}_{3}(\mathrm{aq})\left(10 \% \mathrm{D}_{2} \mathrm{O}\right)$ containing $30 \mathrm{mM}$ TEPDA and 5 $\mathrm{mM} \mathrm{Ru}(\mathrm{NO})^{3+}$ at 356 K. (a): 7.2-8.4 ppm. (b): 0.7-3.4 ppm. 
(a)
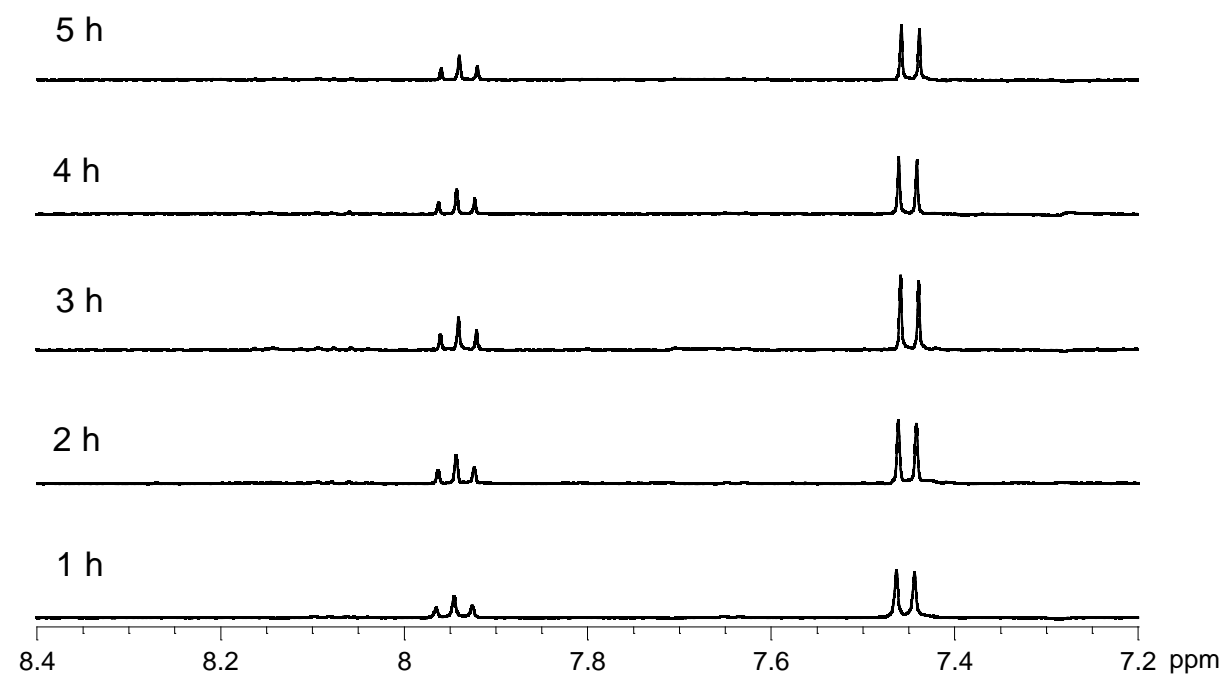

(b)

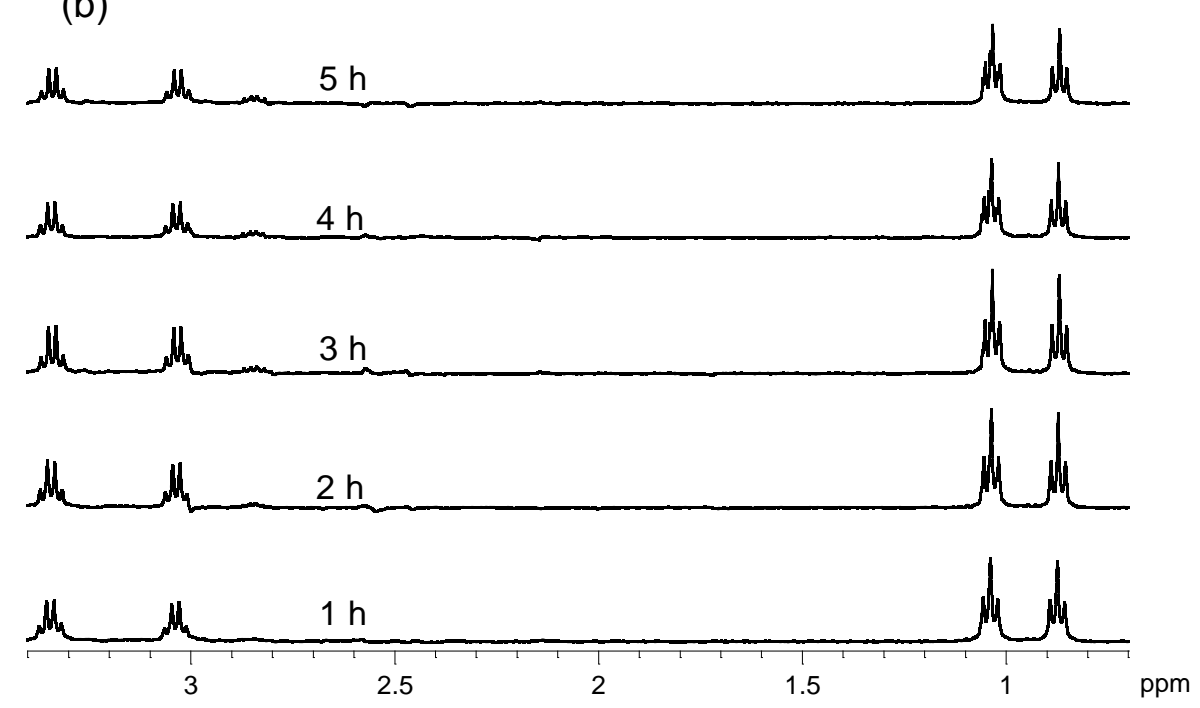

Figure. S27. ${ }^{1} \mathrm{H}$ NMR spectra of $0.5 \mathrm{M} \mathrm{HNO}_{3}(\mathrm{aq})\left(10 \% \mathrm{D}_{2} \mathrm{O}\right)$ containing $30 \mathrm{mM}$ TEPDA and 5 $\mathrm{mM} \mathrm{Rh}^{3+}$ at 356 K. (a): 7.2-8.4 ppm. (b): 0.7-3.4 ppm. 


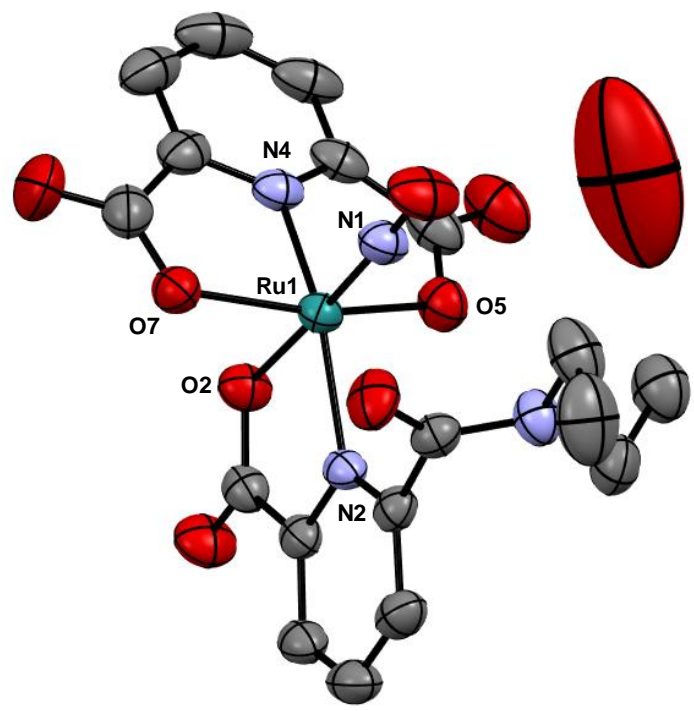

Figure. S28. ORTEP drawing of $\mathrm{Ru}(\mathrm{NO})^{3+}$ complex with 2,6-pyridinedicarboxylate and 6(diethylcarbamoyl)picolinate at the $50 \%$ probability level. Hydrogen atoms were omitted for clarity. Crystallographic data: $F_{\mathrm{w}}=529.42,0.314 \times 0.225 \times 0.121 \mathrm{~mm}^{3}$, monoclinic, $P 121 / \mathrm{cl}$ (No.14), $a=11.9414(4) \AA, b=15.0754(3) \AA, c=12.8497(5) \AA, \beta=116.707(5)^{0}, V=2066.44(14)$ $\AA^{3}, Z=4, T=293 \mathrm{~K}, D_{\text {calcd }}=1.702 \mathrm{~g} \mathrm{~cm}^{-3}, \mu=0.815 \mathrm{~mm}^{-1}, \mathrm{GOF}=0.957, \mathrm{R}(I>2 \sigma)=0.0387$, $w R($ all $)=0.1148$.

Table S1. Calculated Logarithmic Gross Stability Constant $\left(\log \beta_{n}\right)$ of $\left[\mathrm{Ru}(\mathrm{NO})(\mathrm{TEPDA})_{n}\right]^{3+}$ and $\left[\operatorname{Rh}(\mathrm{TEPDA})_{n}\right]^{3+}(n=1,2)$ in Aqueous Phase under Different Concentration of PDA

\begin{tabular}{ccccc}
\hline $\mathrm{C}^{\text {ini }} / \mathrm{mM}$ & \multicolumn{3}{c}{$\mathrm{Ru}(\mathrm{III})$} & \multicolumn{2}{c}{$\mathrm{Rh}(\mathrm{III})$} \\
\hline & $\log \beta_{1}$ & $\log \beta_{2}$ & $\log \beta_{1}$ & $\log \beta_{2}$ \\
5 & 3.49 & 5.66 & 2.84 & 6.26 \\
10 & 3.09 & 6.65 & 2.59 & 5.49 \\
15 & 2.71 & 5.11 & 2.45 & 4.75 \\
30 & 2.88 & 4.66 & 2.28 & 4.02 \\
av. $\pm \mathbf{2 \sigma}^{\mathbf{a}}$ & $\mathbf{3 . 0 4} \pm \mathbf{0 . 5 8}$ & $\mathbf{5 . 5 2} \pm \mathbf{1 . 4 8}$ & $\mathbf{2 . 5 4} \pm \mathbf{0 . 4 1}$ & $\mathbf{5 . 1 3} \pm \mathbf{1 . 6 7}$ \\
\hline
\end{tabular}

a: av : Average, $\sigma$ : Standard Deviation 